\title{
Metode Parametrik Untuk Menghitung Premi Program Asuransi Usaha TANi PADI Di INDONESIA
}

\author{
${ }^{1}$ Aceng Komarudin Mutaqin, ${ }^{2}$ Abdul Kudus, ${ }^{3}$ Yayat Karyana \\ Program Studi Statistika, Universitas Islam Bandung, Jl. Ranggamalela No. 1 Bandung \\ Email: aceng.k.mutaqin@gmail.com
}

\begin{abstract}
Abstrak Dalam makalah ini akan diusulkan suatu metode penaksiran besarnya premi program Asuransi Usaha Tani Padi di Indonesia menggunakan pendekatan statistika yang bersifat parametrik dengan mengasumsikan bahwa data hasil panen padi petani mengikuti distribusi normal. Hasil aplikasinya terhadap data produktivitas padi di beberapa kabupaten di provinsi Jawa Barat, menunjukkan bahwa taksiran preminya paling kecil sekitar Rp. 179.000, - dan paling sekitar besar Rp. 268.000,-
\end{abstract}

Kata Kunci: premi, asuransi usaha tani padi, parametrik, distribusi normal.

\section{Pendahuluan}

Berdasarkan hasil Sensus Pertanian Tahun 2013 yang dilakukan oleh Badan Pusat Statistik (BPS), diketahui bahwa sekitar 79,8\% rumah tangga tanaman pangan di Indonesia didominasi oleh rumah tangga yang mengelola tanaman padi (Badan Pusat Statistik, 2013). Petani padi seringkali mengalami kerugian akibat kegagalan panen. Kegagalan panen tersebut dipengaruhi oleh beberapa faktor diantaranya adalah akibat kekeringan, banjir dan Organisme Pengganggu Tanaman (OPT). Pemerintah Indonesia berupaya untuk memberikan perlindungan kepada petani terhadap kegagalan panen dengan membuat program Asuransi Usaha Tani Padi (AUTP).

Pemerintah, dalam hal ini Kementerian Pertanian melakukan uji coba program AUTP pada musim tanam Oktober 2012 sampai Maret 2013 yang dialokasikan pada 3 provinsi yaitu Jawa Barat, Jawa Timur dan Sumatera Selatan, dengan proyeksi areal masing-masing seluas 1.000 hektar. Uji coba tersebut melibatkan PT. Jasindo sebagai pelaksana asuransi. Dalam rangka kemitraan dengan petani, pemerintah memberikan subsidi untuk pembayaran premi asuransi sebesar 80\% (Rp. 144.000,-/hektar), sedangkan sisanya sebesar $20 \%$ (Rp. 36.000,-/hektar) menjadi tanggungan petani (Supartoyo, dan Kasmiati, 2013). Pemerintah didorong untuk segera merealisasikan program AUTP sebagaimana yang diamanatkan dalam Undang-Undang No. 19 Tahun 2013 tentang Perlindungan dan Pemberdayaan Petani, Pasal 37-39 tentang Asuransi Pertanian. Pada tahun 2014, Kementerian Pertanian sedang melakukan tahap persiapan program AUTP, dan ditargetkan program tersebut dapat diterapkan pada tahun 2015.

Di beberapa negara, asuransi pertanian (crop insurance) sudah ada sejak lama, seperti di Amerika, Jepang dan Brazil masing-masing sudah ada sejak tahun 1899, 1939, dan 1954 (Hazell, dkk., 1986). Asuransi pertanian sudah ada di negara Cina sejak 
tahun 1949 (Wang, dkk, 2010), sedangkan di India sejak tahun 1979 (Sharma, 2001). Sementara itu di Meksiko dan Canada masing-masing sudah ada sejak tahun 1961 dan 1964. Di negara Thailand, asuransi pertanian yang terkait dengan tanaman padi sudah dimulai tahun 2008, sedangkan di Malaysia mulai tahun 2013.

Salah satu tahapan penting dalam proses industri bisnis asuransi adalah penetapan besarnya premi yang harus dibayarkan oleh pemegang polis (Grize, 2014). Begitu juga halnya dalam bisnis asuransi pertanian. Premi yang ditetapkan oleh perusahaan asuransi jangan terlalu besar, juga jangan terlalu kecil. Jika premi yang ditetapkan terlalu besar, maka para petani sebagai peserta asuransi pertanian akan mengalami kerugian. Sebaliknya jika premi yang ditetapkan terlalu kecil, maka perusahaan asuransi pertanian akan mengalami kerugian. Oleh karena itu dibutuhkan suatu metode yang mampu menghitung besarnya premi untuk asuransi pertanian yang adil bagi kedua belah pihak.

Beberapa metode untuk menghitung besarnya premi asuransi pertanian telah dibahas oleh banyak peneliti. Metode-metodenya didasarkan pada data hasil panen pertanian. Hasil penelitian literatur dari Rao (2001) menunjukkan bahwa ada tiga metode umum yang digunakan untuk menghitung besarnya premi asuransi pertanian, yaitu metode judgement, metode loss ratio, dan metode pure premium (loss cost). Metode judgement merupakan metode yang paling tua yang menggunakan intuisi dari ahli untuk menetapkan premi. Metode ini sangat bermanfaat dalam menetapkan premi untuk asuransi pertanian yang baru. Metode pure premium menghitung premi baru setiap waktu metode tersebut digunakan, sedangkan metode loss ratio menyesuaikan premi yang telah dibuat sebelumnya. Botts dan Bales (1958) dalam Bharamappanavara dkk. (2010) dan Goodwin (1994) membahas metode kurva normal. Metode ini mengasumsikan bahwa distribusi hasil panen pertaniannya adalah normal. Metode yang sifatnya empirik dibahas oleh Goodwin (1994) dan Hatt dkk. (2012). Metode ini didasarkan pada hubungan rata-rata kerugian empirik dengan pertanggungan. Metode yang melibatkan hukum peluang dibahas oleh Babcock dkk. (2004). Ozaki dkk. (2008) membahas metode parametrik dan nonparametrik untuk menghitung premi asuransi pertanian. Metode parametrik mengasumsikan bahwa hasil panen pertaniannya mengikuti distribusi tertentu seperti distribusi normal, distribusi beta, dan distribusi gamma. Sedangkan metode nonparametrik menggunakan histogram dan penaksir Kernel untuk menaksir distribusi dari hasil panen pertanian. Metode yang sifatnya Bayes dibahas oleh Ozaki (2009), Ozaki dan Silva (2009), dan Ramadan (2011). Wang dkk. (2010) menerapkan model analisis survival untuk merancang premi asuransi pertanian. Woodard dkk. (2011) membahas metode Loss Cost Ratio (LCR). Metode LCR digunakan untuk menghitung besarnya premi asuransi pertanian dengan jalan merata-ratakan rasio biaya kerugian untuk setiap titik waktu untuk semua peserta asuransi pada tingkat daerah. Metode LCR mengasumsikan bahwa nilai pertanggungan dan harapan ganti ruginya konstan sepanjang waktu. Sedangkan Chakrabarti (2014) membahas metode technical premium untuk menghitung premi asuransi pertanian dengan melibatkan biaya-biaya atau faktor loading. 
Ketika program AUTP diterapkan di Indonesia pada tahun 2012-2013, cakupan lahan padi yang dapat dilaksanakan oleh PT. Jasindo seluas 623,12 hektar dengan total premi yang terkumpul sebesar Rp. 112.100.000,- Luas lahan padi petani yang terkena gagal panen seluruhnya mencapai 87,28 hektar dengan klaim yang diajukan sebesar Rp. 523.700.000,- atau 467\% dari nilai premi yang diterima PT. Jasindo (Supartoyo, dan Kasmiati, 2013). Oleh karena itu PT. Jasindo mengalami kerugian. Berdasarkan kejadian tersebut dibutuhkan metode yang tepat untuk menghitung besarnya premi program asuransi AUTP berdasarkan data hasil panen padi di Indonesia. Besarnya premi yang ditetapkan oleh pemerintah Indonesia untuk uji coba program asuransi AUTP tahun 2012-2013 didasarkan pada persentase nilai pertanggungan per hektar, yaitu sebesar 3\% per hektar dari nilai pertanggungan Rp. 6.000.000,- atau sebesar Rp. 180.000,- Tujuan dari penulisan makalah ini adalah untuk merumuskan metode perhitungan premi program asuransi AUTP di Indonesia yang didasarkan pada data hasil panen padi yang sifatnya parametrik dengan mengasumsikan bahwa data hasil panen padinya berasal dari suatu populasi yang berdistribusi normal. Metode yang dirumuskan akan diaplikasikan pada data produktivitas padi di beberapa kabupaten di provinsi Jawa Barat.

\section{Program Asuransi AUTP di Indonesia}

Sejarah asuransi pertanian di Indonesia dimulai tahun 1982 dengan dibentuknya Kelompok Kerja Persiapan Pengembangan Asuransi Panen (Supartoyo dan Kasmiati, 2013). Pembentukan kelompok tersebut dilakukan lagi pada tahun 1984 dan 1985. Pada tahun 1999, pengembangan asuransi pertanian dicanangkan lagi. Pembahasan secara serius dilakukan, tetapi untuk melangkah ke tahap implementasi perlu pertimbangan yang matang.

Pada tahun 2012 sampai 2013 pemerintah Indonesia mulai melakukan uji coba Asuransi Usaha Tani Padi (AUTP) di tiga provinsi, yaitu Jawa Barat, Jawa Timur dan Sumatera Selatan, dengan proyeksi areal masing-masing seluas 1.000 hektar. Uji coba tersebut melibatkan PT. Jasindo sebagai pelaksana asuransi. Pemerintah memberikan subsidi untuk pembayaran premi asuransi sebesar 80\% (Rp. 144.000,-/hektar), sedangkan sisanya sebesar $20 \%$ (Rp. 36.000,-/hektar) menjadi tanggungan petani (Supartoyo, dan Kasmiati, 2013).

Pada pelaksanaannya cakupan lahan padi yang dapat dilaksanakan oleh PT. Jasindo seluas 623,12 hektar dengan total premi yang terkumpul sebesar Rp. 112.100.000,- Luas lahan padi petani yang terkena gagal panen seluruhnya mencapai 87,28 hektar dengan klaim yang diajukan sebesar Rp. 523.700.000,- atau 467\% dari nilai premi yang diterima PT. Jasindo (Supartoyo, dan Kasmiati, 2013).

Beberapa hal penting terkait dengan skema asuransi AUTP di Indonesia adalah:

1. Peserta asuransi dalam hal ini petani maksimal lahanya seluas 2 hektar.

2. Nilai pertanggungan adalah Rp. 6.000.000,- per hektar. 
3. Premi asuransi AUTP adalah sebesar 3\% dari nilai pertanggungan atau sebesar Rp. 180.000,- per hektar. Pemerintah memberikan subsidi sebesar $80 \%$ atau Rp. 144.000,- per hektar, sedangkan petani membayar sebesar $20 \%$ atau Rp. 36.000,- per hektar.

4. Jenis risiko yang dapat diasuransikan adalah kekeringan, banjir dan serangan Organisme Pengganggu Tumbuhan (OPT).

5. Jangka waktu pertanggungan asuransi berlaku untuk satu musim tanam.

6. Petani yang hanya panen maksimal sebesar $25 \%$ dari area yang ditanam akan memperoleh ganti rugi penuh sebesar Rp. 6.000.000,- Untuk kasus lainnya tergantung pada tingkat kerusakan dan usia tanam (Pasaribu, 2010).

\section{Distribusi Normal sebagai Salah Satu Distribusi Hasil Panen}

Untuk pendekatan yang sifatnya parametrik, penentuan besarnya premi asuransi pertanian didasarkan pada distribusi dari hasil panen. Salah satu distribusi tersebut adalah distribusi normal. Misalkan peubah acak $Y$ berdistribusi normal, dengan parameter lokasi $-\infty<\mu<\infty$ dan parameter skala $\sigma^{2}>0$. Fungsi densitas dari peubah acak tersebut adalah:

$g(y)=\frac{1}{\sigma \sqrt{2 \pi}} \exp \left[-\frac{1}{2}\left(\frac{y-\mu}{\sigma}\right)^{2}\right] ;-\infty<y<\infty$.

Rata-rata dan varians dari peubah acak $Y$ masing-masing adalah $E(Y)=\mu$ dan $\operatorname{Var}(Y)=\sigma^{2}$.

Misalkan $Y_{1}, Y_{2}, \cdots, Y_{n}$ merupakan sampel acak berukuran $n$ dari distribusi normal di atas, maka taksiran parameter $\mu$ dan $\sigma^{2}$ dengan menggunakan metode kemungkinan maksimum (maximum likelihood estimation) masing-masing adalah $\hat{\mu}=\bar{Y}=\frac{1}{n} \sum_{i=1}^{n} Y_{i}$, dan $\hat{\sigma}^{2}=\frac{1}{n} \sum_{i=1}^{n}\left(Y_{i}-\bar{Y}\right)^{2}$. Taksiran $\hat{\sigma}^{2}$ bersifat bias. Taksiran takbiasnya adalah $S^{2}=\frac{1}{n-1} \sum_{i=1}^{n}\left(Y_{i}-\bar{Y}\right)^{2}$.

\section{Metode Perhitungan Premi Asuransi Pertanian}

Beberapa metode telah diusulkan untuk menghitung besarnya premi asuransi pertanian. Dalam bagian ini akan dibahas metode kurva normal dan metode yang sifatnya parametrik.

\subsection{Metode Kurva Normal}

Metode ini pertama kali diusulkan oleh Botts dan Boles tahun 1958 dengan mengasumsikan bahwa data hasil panen pertanian berdistribusi normal dengan parameter $\mu$ dan $\sigma^{2}$. Jika koefisien variasinya sama dengan 0,25 atau $\sigma=0,25 \mu$, maka besarnya premi asuransi pertanian untuk cakupan $\alpha \times 100 \%$ dalam bentuk rate adalah

$$
\text { rate }=\Phi((\alpha \mu-\mu) / 0,25 \mu)(\alpha \mu-\mu)+\phi((\alpha \mu-\mu) / 0,25 \mu) 0,25 \mu \text {, }
$$


dimana $\Phi(\cdot)$ adalah fungsi distribusi kumulatif normal dan $\phi(\cdot)$ adalah nilai fungsi densitas normal. Penjelasan lebih rinci mengenai metode kurva normal dapat dilihat dalam Ray (1981).

\subsection{Metode Parametrik}

Metode parametrik mengasumsikan bahwa hasil panen pertaniannya mengikuti distribusi tertentu seperti distribusi normal, distribusi beta, dan distribusi gamma. Peluang kerugian hasil panen pertanian sama dengan area daerah di bawah kurva fungsi densitas ketika hasil panen lebih kecil dibandingkan dengan hasil yang dijamin. Misalkan $\lambda$ menyatakan tingkat cakupan (level of coverage), dengan $0<\lambda<1$, dan $y^{e}$ menyatakan ekspektasi dari hasil panen. Peluang kerugian dapat dihitung melalui area di bawah fungsi densitas dengan menggunakan aturan trapezoid untuk menaksirnya secara numerik. Besarnya premi dalam bentuk rate diberikan oleh Goodwin dan Ker (1998) dalam Ozaki dkk. (2008):

$$
\text { premium rate }=\frac{F_{Y}\left(\lambda y^{e}\right) E_{Y}\left(\lambda y^{e}-\left(Y \mid y<\lambda y^{e}\right)\right)}{\lambda y^{e}},
$$

dimana $E$ menyatakan operator ekspektasi dan $F$ menyatakan fungsi distribusi kumulatif.

\section{Metode Parametrik untuk Menghitung Premi Program AUTP}

Misalkan $Y$ adalah peubah acak rata-rata hasil panen padi per hektar dari seorang petani, dengan fungsi densitas $g(y)$ dan ekspektasi $E(Y)$. Dalam program asuransi AUTP disebutkan bahwa petani yang hanya panen maksimal sebesar $25 \%$ dari area yang ditanam akan memperoleh ganti rugi penuh sebesar Rp. 6.000.000,Sedangkan untuk kasus lainnya tergantung pada tingkat kerusakan dan usia tanam (Pasaribu, 2010). Dengan mengacu pada pernyataan di atas, maka dapat dirumuskan besarnya ganti rugi untuk program asuransi AUTP. Misalkan I menyatakan peubah acak besarnya ganti rugi (dalam juta rupiah), maka

$$
I= \begin{cases}6 & ; \text { untuk } Y \leq 0,25 E(Y), \\ \frac{8}{E(Y)}(E(Y)-Y) & ; \text { untuk } 0,25 E(Y)<Y<E(Y), \\ 0 & ; \text { untuk } Y \geq E(Y) .\end{cases}
$$

Besarnya premi (rupiah) program asuransi AUTP yang adil secara aktuaria adalah ekspektasi dari peubah acak besarnya ganti rugi, yaitu

$$
\begin{aligned}
E(I)= & 6 P(Y \leq 0,25 E(Y)) \\
& +E\left[\frac{8}{E(Y)}(E(Y)-Y) \mid 0,25 E(Y)<Y<E(Y)\right] \times \\
& P(0,25 E(Y)<Y<E(Y)) . \\
& \text { Dalam makalah ini akan dibatasi bahwa peubah acak } Y \text { diasumsikan }
\end{aligned}
$$
berdistribusi normal dengan fungsi densitas sebagaimana dalam Persamaan (1). Dapat 
ditunjukkan bahwa besarnya premi program asuransi AUTP yang adil secara aktuaria untuk kasus ini adalah

$E(I)=6 \Phi\left(\frac{-0,75 \mu}{\sigma}\right)-8 \frac{\sigma}{\mu}\left[\phi\left(\frac{-0,75 \mu}{\sigma}\right)-\frac{1}{\sqrt{2 \pi}}\right]$

dimana $\phi(\cdot)$ dan $\Phi(\cdot)$ masing-masing menyatakan nilai fungsi densitas peluang dan nilai fungsi distribusi kumulatif dari distribusi normal baku.

Dengan menggunakan prinsip plug-in, maka taksiran besarnya premi program asuransi AUTP untuk kasus distribusi normal adalah sama sebagaimana di atas, namun parameter $\mu$ dan $\sigma$ diganti oleh taksirannya yang tak bias, yaitu

$E(I)=6 \Phi\left(\frac{-0,75 \bar{Y}}{S}\right)-8 \frac{S}{\bar{Y}}\left[\phi\left(\frac{-0,75 \bar{Y}}{S}\right)-\frac{1}{\sqrt{2 \pi}}\right]$

\section{Aplikasi}

Metode perhitungan premi untuk program asuransi AUTP di Indonesia akan diterapkan pada data produktivitas padi di beberapa kabupaten di provinsi Jawa Barat periode tahun 1990 s/d 2013 yang ada pada Tabel 1.

\section{Tabel 1. Data Produktivitas Padi (Ku/Ha) di 14 Kabupaten di Jawa Barat}

\begin{tabular}{|c|c|c|c|c|c|c|c|c|c|c|c|c|c|c|}
\hline Tahun & 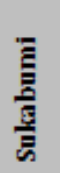 & 兽 & 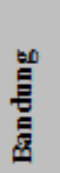 & 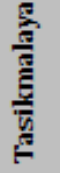 & 品 & 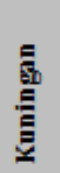 & 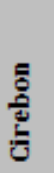 & 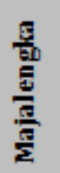 & 毞 & 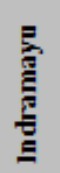 & $\frac{\text { 皆 }}{\bar{E}}$ & 焉 & 紫 & 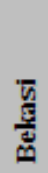 \\
\hline 1990 & 46 & 45 & 50 & 46 & 50 & 50 & 54 & 51 & 50 & 50 & 51 & 45 & 54 & 53 \\
\hline 1991 & 47 & 46 & 48 & 49 & 50 & 50 & 53 & 51 & 50 & 52 & 54 & 47 & 55 & 51 \\
\hline 1992 & 47 & 45 & 48 & 48 & 49 & 50 & 54 & 52 & 50 & 52 & 54 & 47 & 55 & 51 \\
\hline 1993 & 48 & 46 & 49 & 49 & 50 & 51 & 54 & 53 & 50 & 52 & 54 & 47 & 55 & 51 \\
\hline 1994 & 48 & 47 & 49 & 49 & 50 & 51 & 54 & 53 & 50 & 52 & 54 & 48 & 55 & 52 \\
\hline 1995 & 49 & 47 & 49 & 48 & 50 & 51 & 54 & 53 & 50 & 52 & 54 & 47 & 55 & 52 \\
\hline 1996 & 47 & 47 & 49 & 49 & 51 & 52 & 55 & 54 & 51 & 53 & 55 & 47 & 56 & 52 \\
\hline 1997 & 47 & 47 & 50 & 49 & 51 & 52 & 55 & 54 & 51 & 54 & 55 & 47 & 56 & 52 \\
\hline 1998 & 43 & 43 & 49 & 46 & 45 & 48 & 50 & 51 & 48 & 42 & 47 & 43 & 42 & 43 \\
\hline 1999 & 44 & 45 & 46 & 46 & 48 & 49 & 43 & 48 & 49 & 50 & 48 & 44 & 51 & 43 \\
\hline 2001 & 44 & 46 & 48 & 48 & 50 & 50 & 54 & 52 & 50 & 54 & 51 & 45 & 53 & 49 \\
\hline 2002 & 46 & 48 & 49 & 49 & 51 & 51 & 56 & 54 & 52 & 56 & 52 & 46 & 54 & 51 \\
\hline 2003 & 48 & 48 & 54 & 48 & 52 & 56 & 55 & 54 & 51 & 55 & 55 & 50 & 56 & 54 \\
\hline 2004 & 48 & 48 & 50 & 49 & 53 & 50 & 54 & 53 & 50 & 55 & 52 & 50 & 54 & 48 \\
\hline 2005 & 48 & 49 & 50 & 50 & 52 & 52 & 51 & 55 & 52 & 55 & 53 & 49 & 52 & 54 \\
\hline 2006 & 50 & 50 & 52 & 52 & 54 & 53 & 52 & 54 & 53 & 53 & 54 & 50 & 54 & 52 \\
\hline 2007 & 50 & 50 & 56 & 53 & 57 & 54 & 58 & 55 & 53 & 57 & 55 & 54 & 54 & 54 \\
\hline 2008 & 51 & 53 & 58 & 60 & 60 & 57 & 57 & 55 & 54 & 56 & 58 & 53 & 59 & 55 \\
\hline 2009 & 55 & 53 & 58 & 60 & 63 & 57 & 59 & 59 & 56 & 58 & 60 & 56 & 59 & 59 \\
\hline 2010 & 55 & 54 & 59 & 62 & 62 & 57 & 57 & 56 & 56 & 56 & 54 & 56 & 59 & 58 \\
\hline 2011 & 56 & 57 & 60 & 60 & 60 & 61 & 62 & 60 & 58 & 61 & 60 & 57 & 60 & 58 \\
\hline 2013 & 51 & 58 & 68 & 63 & 60 & 59 & 64 & 61 & 62 & 62 & 59 & 54 & 61 & 58 \\
\hline
\end{tabular}

Sumber: Kementerian Pertanian Republik Indonesia (2014) 
Tabel 2. Ringkasan Statistik dan Taksiran Premi

\begin{tabular}{|c|c|c|c|c|c|c|c|c|c|c|c|c|c|c|}
\hline & $\begin{array}{l}\text { 普 } \\
\text { 恶 }\end{array}$ & 䇏 & 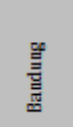 & 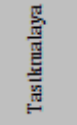 & $\begin{array}{l}\frac{n}{E} \\
\frac{\underline{U}}{6}\end{array}$ & 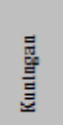 & $\begin{array}{l}\bar{g} \\
\frac{\mathrm{g}}{0}\end{array}$ & 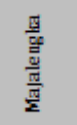 & 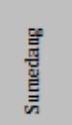 & 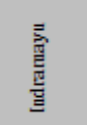 & $\begin{array}{l}\text { 哭 } \\
\text { 恶 }\end{array}$ & 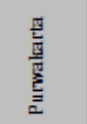 & 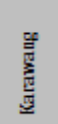 & $\begin{array}{l}\overrightarrow{\underline{v}} \\
\frac{\mathrm{g}}{\mathrm{g}}\end{array}$ \\
\hline Rata-rata & 48,55 & 48,73 & 52,23 & 51,50 & 53,09 & 52,77 & 54,77 & 54,00 & 52,09 & 53,95 & 54,05 & 49,18 & 54,95 & 52,27 \\
\hline $\begin{array}{l}\text { Simpangan } \\
\text { Baku }\end{array}$ & 3,46 & 3,98 & 5,41 & 5,55 & 4,97 & 3,53 & 4,19 & 3,02 & 3,34 & 4,09 & 3,30 & 4,12 & 3,87 & 4,19 \\
\hline P-Value & 0,057 & 0,014 & $<0,005$ & $<0,005$ & $<0,005$ & 0,006 & 0,021 & 0,036 & $<0,005$ & 0,102 & 0,041 & 0,039 & 0,005 & 0,057 \\
\hline $\begin{array}{l}\text { Taksiran } \\
\text { Premi }\end{array}$ & 227.495 & 260.570 & & & & & 243.876 & 178.709 & & 241.818 & 194.987 & 267.661 & & 255.713 \\
\hline
\end{tabular}

Tabel 2 berisikan ringkasan statistik (rata-rata dan simpangan baku) serta nilai pvalue dari pengujian kecocokan distribusi normal menggunakan uji Anderson-Darling dengan bantuan perangkat lunak Minitab 17. Dengan menggunakan taraf nyata $\alpha=1 \%$, dari 14 kabupaten yang data produktivitas padinya lengkap, ada 6 kabupaten yang datanya tidak berdistribusi normal, yaitu Kabupaten Bandung, Kabupaten Tasikmalaya, Kabupaten Ciamis, Kabupaten Kuningan, Kabupaten Sumedang dan Kabupaten Karawang. Data tersebut tidak akan digunakan pada langkah selanjutnya, yaitu menghitung taksiran besarnya premi. Nilai taksiran besarnya premi program AUTP di Indonesia untuk beberapa kabupaten di provinsi Jawa Barat disajikan dalam Tabel 2 baris terakhir.

\section{Kesimpulan}

Dalam makalah ini diusulkan metode penaksiran besarnya premi program asuransi AUTP di Indonesia yang rencananya akan digulirkan di tahun 2015 ini menggunakan pendekatan statistika yang bersifat parametrik dengan mengasumsikan bahwa data rata-rata hasil panen padi per hektar mengikuti distribusi normal. Hasil aplikasi dari metode yang diusulkan terhadap data produktivitas padi di beberapa kabupaten di provinsi Jawa Barat, menunjukkan bahwa taksiran preminya paling kecil sekitar Rp. 179.000,- dan paling sekitar besar Rp. 268.000,- Selain itu, tidak semua data dapat diolah menggunakan metode yang diusulkan karena tidak semuanya berdistribusi normal.

\section{Daftar Pustaka}

Babcock, B. A., Hart, C. E., Hayes, D. J. 2004. Actuarial Fairness of Crop Insurance Rates with Constant Rate Relativities. American Journal of Agricultural Economics: Vol. 86, No. 3, 563-575.

Badan Pusat Statistik (BPS). 2013. Laporan Hasil Sensus Pertanian 2013 (Pencacahan Lengkap). Badan Pusat Statistik. http://st2013.bps.go.id/st2013esya/booklet/at0000.pdf. Diunduh pada tanggal 20 November 2014.

Bharamappanavara, S. C., Hasanabadi, M. S., Handigol, J. A., Yeledalli, R. A. 2010. Alternative Model for Crop Insurance - A Case of Onion Crop (Allium Cepa). 
Proceedings of The International Conference On Applied Economics - ICOAE 2010, 85-90.

BPS Provinsi Jawa Barat. 2015. Produksi Padi, Jagung, dan Kedelai (Angka Sementara Tahun 2014). Berita Resmi Statistik: No. 19/03/32/Th. XVII, 2 Maret 2015.

Chakrabarti, T. 2014. Crop Insurance: An Actuarial Perspective. http://www. actuariesindia.org/\%28X\%281\%29S\%28ykvdba4550txwoersp1tkw55\%29\%29/mic b/wci2014/Tania-Chakrabarti.pdf. Diunduh pada tanggal 20 November 2014.

Goodwin, B. K. 1994. Premium Rate Determination in the Federal Crop Insurance Program: What Do Averages Have to Say About Risk? Journal of Agricultural and Resource Economics: Vol. 19, No. 2, 382-395.

Grize, Y.-L. 2014. Applications of Statistics in the Field of General Insurance: An Overview. International Statistical Review, 1-25, doi:10.1111/insr.12066.

Hatt, M., Heyhoe, E., Whittle, L. 2012. Options for Insuring Australian Agricultural. Department of Agricultural, Fisheries and Forestry, Australian Bureau of Agricultural and Resource Economics and Sciences (ABARES). http://www.daff.gov.au/SiteCollectionDocuments/ag-food /drought/ec/nrac/workprog/abares-report/abares-report-insurance-options.pdf. Diunduh pada tanggal 20 November 2014.

Hazell, P., Pomareda, C., Valdes, A. 1986. Crop Insurance for Agricultural Development: Issues and Experience. The Johns Hopkins Press Ltd., London.

Ozaki, V. A. 2009. Pricing Farm-Level Agricultural Insurance: A Bayesian Approach. Empirical Economics: Vol. 36, 231-242.

Ozaki, V. A., Goodwin, B. K., Shirota, R. 2008. Parametric and Nonparametric Statistical Modelling of Crop Yield: Implications for Pricing Crop Insurance Contracts. Applied Economics: Vol. 48, 1151-1164.

Ozaki, V. A., Silva, R. S. 2009. Bayesian Ratemaking Procedure of Crop Insurance Contracts with Skewed Distribution. Journal of Applied Statistics: Vol. 36, No. 4, 443-452.

Pasaribu, S. M. 2010. Developing Rice Farm Insurance in Indonesia. Agriculture and Agricultural Science Procedia: Vol. 1, 33-41.

Ramadan, A. 2011. Empirical Bayes Nonparametric Density Estimation of Crop Yield Densities: Rating Crop Insurance Contracts. Thesis Program Master di The Faculty of Graduate Studies of The University of Guelph.

Rao, K. N. 2001. Actuarial Premium Rating in Crop Insurance. Journal of the Indian Society of Agricultural Statistics: Vol. 54, No. 1, 139-173.

Ray, P. K. 1981. Agricultural Insurance: Theory and Practice and Application to Developing Countries. Pergamon Press, New York.

Sharma, B. M. 2001. Role of Yield Data in National Agricultural Insurance Scheme. Journal of the Indian Society of Agricultural Statistics: Vol 54, No. 1, 139-173.

Supartoyo, Y. H., Kasmiati. 2013. Asuransi Pertanian sebagai Alternatif Mengatasi

Risiko Usaha Tani Menuju Pertanian Berkelanjutan: Tinjauan Konseptual. https://www.academia.edu/4766244/ASURANSI 
326 | Aceng Komarudin Mutaqin, et al.

_PERTANIAN_SEBAGAI_ALTERNATIF_MENGATASI_RISIKO_USAHA_TA

NI_MENUJU_PERTANIAN_BERKELANJUTAN. diunduh pada tanggal 20 November 2014.

Wang, E., Yu, Y., Little, B. B., Li, Z. 2010. Crop Insurance Premium Design Based on Survival Analysis Model. Agriculture and Agricultural Science Prosedia: 1, 67-75.

Woodard, J. D., Sherrick, B. J., Schnitkey, G. D. 2011. Actuarial Impacts of Loss Cost

Ratio Ratemaking in U.S. Crop Insurance Programs. Journal of Agricultural and Resource Economics: Vol. 36, No. 1, 211-228. 